receive $80 \mathrm{mg}$ fenfluramine daily. It is associated with an increase in intrasleep restlessness, during which more frequent spontaneous shifts to stage 1 sleep occur. ${ }^{19}$ Patients may be more conscious of their dreams during the periods of intrasleep restlessness. Phenothiazines, monoamine oxidase inhibitors, tricyclic antidepressants, amphetamines, and alcohol reduce REM sleep to below normal levels. ${ }^{20-22}$ When these drugs are withdrawn an REM sleep rebound takes place, and the patient spends a higher proportion of the night than usual in dreaming sleep. Dreams become particularly vivid and disturbing. ${ }^{20}$ Total withdrawal of vitamin $C$ from the diet did not change the dream pattern induced by fenfluramine when compared with the pattern reported by subjects receiving a daily intake of $40 \mathrm{mg}$ with the fenfluramine. Dreaming has not been reported in scorbutic patients, ${ }^{23}$ and dreaming is not described as a mental change that accompanies scurvy. ${ }^{24}$ Our results show that there is a definite relation between the dose of fenfluramine administered and the degree of change in sleep pattern.

Depression and acute psychotic episodes have been reported during or immediately after fenfluramine treatment. ${ }^{25-27}$ It seems that fenfluramine played a part in precipitating psychotic decompensation in three patients, in two of whom there was a previous history of mental illness. ${ }^{28}$ One patient in our study complained of nightmares while on fenfluramine and developed a severe depressive illness. Fenfluramine was discontinued and her depression rapidly resolved. Hence, as well as its doserelated weight-reducing and anorectic actions, fenfluramine also exerts dose-related central effects, which may assume undesirable toxic proportions. Patients who dream or have nightmares while on fenfluramine may develop an acute psychotic episode. This possibility should be recognised when its use is contemplated in patients with a history of mental disease or in whom the disease is inadequately controlled with other drugs.

\section{References}

1 Duncan, E H, et al, British fournal of Clinical Practice, 1965, 19, 451.

2 Brodrin, P, and O'Connor, C A, Practitioner, 1967, 198, 707.

${ }^{3}$ Le Dauarec, J C, et al, Annals of the Rheumatic Diseases, 1966, 25, 425.

${ }^{4}$ Oswald, I, Pharmacological Reviews, 1968, 20, 273.

5 Jouvet, M, Science, 1969, 163, 32.

6 Wyatt, R J, Biological Psychiatry, 1972, 5, 33.

' Samanin, R, et al, European fournal of Pharmacology, 1972, 19, 318.

${ }^{8}$ Odumosu, A, and Wilson, C W M, British fournal of Pharmacology, $\underset{\mathrm{G}}{\overrightarrow{\mathrm{S}}}$ $1974,50,471$.

9 Odumosu, A, and Wilson, C W M, British fournal of Pharmacology, 1975, $54,226$.

${ }^{10}$ Wilson, C W M, et al, Recent Advances in Obesity Research, 1, ed A $\overline{\bar{\omega}}$ Howard, p 77. London, Newman Publishing, 1975.

11 Wilson, C W M, Greene, M, and Molloy, T, paper presented at 6 th $\stackrel{\mathbb{D}}{\varrho}$ International Congress of Pharmacology, Helsinki, 1975.

12 Alvi, M J, British Medical fournal, 1969, 3, 237.

13 Hooper, A G, Fournal of the Irish Medical Association, 1972, 65, 35.

${ }_{14}$ Firth, H, et al, British fournal of Pharmacology, 1970, 39, 462.

15 Oswald, I, and Chacore, V R, British Medical fournal, 1963, 2, 427.

${ }^{16}$ Bruce, R B, and Maynard, W R, Fournal of the Pharmaceutical Sciences, 1968, 57, 1173.

17 Paddach, R, et al, Clinical Pharmacology and Therapeutics, 1969, 10, 355.3

18 Spence, A W, and Medrei, V, British fournal of Clinical Practice, 1966, $20,643$.

19 Lewis, S A, Oswald, I, and Dunleavy, D L F, British Medical fournal, O $1971,3,67$.

${ }^{20}$ Hartman, E, Psychophysiology, 1968, 5, 207.

21 Kales, A, Annals of Internal Medicine, 1969, 10, 591.
22 Kales, A, et al, Sleep Physiology and Pathology. Ed A Kales. Philadelphia, 은 Lippincott, 1969.

${ }^{23}$ Kinsman, R A, and Hood, J, American fournal of Clinical Nutrition, 1971, 24, 455 .

24 Wilson, C W M, Practitioner, 1974, 212, 481.

25 Oswald, I, et al, British Medical fournal, 1971, 3, 70

${ }^{26}$ Steel, J M, and Briggs, M, British Medical fournal, 1972, 3, 26.

27 Harding, T, British fournal of Psychiatry, 1972, 121, 338.

${ }^{28}$ Sharman, B J, Leonard, D, and Kidson, M A, British Medical fournal, V 1974, 3, 576.

\title{
Influence of simultaneous low amniotomy and oxytocin infusion and other maternal factors on neonatal jaundice: a prospective study
}

\author{
W C CHEW， I L SWANN
}

British Medical fournal, 1977, 1, 72-73

\begin{abstract}
Summary
In a prospective study of 196 consecutive single births a significant increase in serum bilirubin concentrations was found in infants born after low amniotomy induction and oxytocin infusion compared with those born spontaneously. This relationship was not dose-dependent and may have been associated with artificial interruption of pregnancy rather than the oxytocin itself. Infants delivered after spontaneous labour accelerated by oxytocin showed no such increase. The hormonal surge at the spontaneous onset of labour may affect fetal enzyme induction, but other factors, such as methods of infant feeding and oral contraceptive use, were found not to be significant.
\end{abstract}

Elsie Inglis Maternity Hospital, Abbeyhill, Edinburgh 8

W C CHEW, FRCS, MRCOG, registrar in obstetrics

I L SWANN, MRCP, DCH, registrar in paediatrics

\section{Introduction}

The use of oxytocin infusion to induce labour is now routine $\frac{D}{0}$ in many centres. Simultaneous surgical and medical induction has been advocated, ${ }^{2}$ and the interval between induction and ${ }_{N}$ delivery has been reduced to about eight hours. ${ }^{3}{ }^{4}$ Hazards $\omega$ of these procedures, however, include fetal distress and low Apgar scores. ${ }^{j}$ Oxytocin has been implicated in an increased incidence of neonatal jaundice, ${ }^{6-8}$ though other workers have $\mathbb{\Phi}$ failed to confirm this. ${ }^{9-11}$

We have carried out a prospective study of the factors implica- $T$ ted in neonatal jaundice and report here the results.

\section{Patients and methods}

A total of 217 consecutive single deliveries at this hospital were considered for the study. Of these, 21 babies were excluded because of incomplete bilirubin data, birth weight below $2500 \mathrm{~g}$, haemolytic disease, neonatal infection, or discharge from hospital within 48 hours. A further 15 infants were delivered by caesarean section. The remaining 181 babies were divided into three groups: A (54 infants), spontaneous onset of labour, no oxytocin used; B (28 infants), spontaneous onset of labour, oxytocin used to accelerate labour; C (99 infants), 
labour induced by low amniotomy and simultaneous oxytocin infusion.

The Tekmar pump was used to administer the intravenous oxytocin. In group $C$ two infusion regimens were used, in 75 cases a low-dose regimen-initially 2 units at 5 drops/min, increasing by 5 drops/min every 30 minutes to a maximum of 4 units at 40 drops/ min-and in 24 cases an accelerated high-dose regimen initially 2 units at $10 \mathrm{drops} / \mathrm{min}$, increasing by $10 \mathrm{drops} / \mathrm{min}$ every 20 minutes to a maximum of 10 units at $60 \mathrm{drops} / \mathrm{min}$. In all cases the infusion rate was adjusted to a maintenance level in which contractions were moderately strong, occurring every two to three minutes, and lasting for 45 seconds.

Cord blood was obtained after delivery (day 1), and the infant's blood collected by heel-prick on the third and sixth postnatal days. Total serum bilirubin was estimated with a spectrophotometer within 24 hours of birth, ${ }^{12}$ the upper limit of normal being taken as $205 \cdot 2 \mu \mathrm{mol} / 1(12.0 \mathrm{mg} / 100 \mathrm{ml})$.

\section{Results}

On days 1,3 , and 6 the mean serum bilirubin concentrations in group $C$ were significantly higher than those in group $A(P<0.05)$ (table I). There were no significant differences, however, between groups $A$ and $B(P>0.05)$. Fifteen of the 99 infants in group $C$ had serum bilirubin concentrations above $205 \cdot 2 \mu \mathrm{mol} / 1$ compared with only one of the 54 infants in group A. There were no significant differences in mean gestational age or birth weight between the three groups (table II).

Table III shows the mean serum bilirubin concentrations for all 196 infants - that is, including the 15 delivered by caesarean sectionrelated to factors known to affect those concentrations. Similar values were found whether the infants were delivered spontaneously, with assistance or by caesarean section. There were no significant differences in concentrations between breast-fed infants and those fed artificially, nor between infants born to mothers who had or had not used oral contraceptives in the previous year.

TABLE I-Mean $( \pm S D)$ total serum bilirubin concentrations ( $\mu$ molll) in the three infant groups

\begin{tabular}{|c|c|c|c|}
\hline & $\underset{(n=54)}{\text { Group A }}$ & $\underset{(n=28)}{\text { Group B }}$ & $\underset{(n=99)}{\text { Group C }}$ \\
\hline $\begin{array}{l}\text { Day } 1 \\
\text { Day } 3 \\
\text { Day } 6\end{array}$ & $\begin{array}{r}39 \cdot 2 \pm 10 \cdot 1 \\
104 \cdot 3+46 \cdot 7 \\
78 \cdot 0 \pm 48 \cdot 7\end{array}$ & $\begin{array}{r}39 \cdot 0 \pm 10 \cdot 8 \\
106.2 \pm 51.0 \\
80.9 \pm 45.5\end{array}$ & $\begin{array}{r}44 \cdot 0 \pm 16 \cdot 6 \\
127 \cdot 9 \pm 55.9 \\
111 \cdot 8 \pm 58 \cdot 5\end{array}$ \\
\hline
\end{tabular}

Conversion: SI to traditional units-Serum bilirubin: $1 \mu \mathrm{mol} / 1 \approx 0.06 \mathrm{mg} / 100 \mathrm{ml}$.

TABLE II-Mean birth weight and gestational age in the three infant groups

\begin{tabular}{l|c|c|c}
\hline & $\begin{array}{c}\text { Group A } \\
(\mathbf{n}=54)\end{array}$ & $\begin{array}{c}\text { Group B } \\
(\mathbf{n}=28)\end{array}$ & $\begin{array}{c}\text { Group C } \\
(\mathrm{n}=99)\end{array}$ \\
\hline Birth weight (g) & 3350 & 3320 & 3300 \\
Gestational age (weeks) & 39.2 & 39.5 & $39 \cdot 1$ \\
\hline
\end{tabular}

TABLE III-Mean $( \pm S D)$ neonatal serum bilirubin concentrations ( $\mu$ mol $/ l$ ) relation to certain maternal and fetal factors

\begin{tabular}{l|c|c}
\hline \multicolumn{1}{c|}{ Factors } & $\begin{array}{c}\text { No of } \\
\text { infants }\end{array}$ & $\begin{array}{c}\text { Serum bilirubin } \\
\text { concentration }\end{array}$ \\
\hline Spontaneous vaginal delivery & 158 & $108.4 \pm 55.9$ \\
Assisted vaginal delivery & 23 & $113.2 \pm 62.2$ \\
Caesarean section & 15 & $11.2 \pm 49 \cdot 2$ \\
Previous oral contraceptive use & 61 & $114.7 \pm 55 \cdot 2$ \\
No previous use of oral contraception & 92 & $119.4 \pm 56.4$ \\
Breast-feeding & 65 & $109.8 \pm 52.1$ \\
Artificial feeding & 113 & $113.5 \pm 53.7$
\end{tabular}

\section{Discussion}

Our finding of significantly increased serum bilirubin concentrations in babies delivered by surgical induction and oxytocin infusion agrees with that of Davies et $a l^{7}$ and of Ghosh and Hudson ${ }^{6}$ but differs from the findings of Gould et $a l^{10}$ and Davidson et al. ${ }^{9}$ Davidson et al found that the mean total bilirubin concentration in cord blood was lower in babies delivered after oxytocin-induced labour. Their sample included only 14 cases, however, and the difference was not statistically significant.

Serum bilirubin concentrations above $205.2 \mu \mathrm{mol} / 1$ in fullterm infants should always be regarded as abnormal. ${ }^{13}$ In our series 15 of the 99 infants delivered by oxytocin induction had serum bilirubin concentrations greater than $205.2 \mu \mathrm{mol} / 1 \mathrm{com}-$ pared with one of the 54 delivered without oxytocin.

Beazley and Alderman ${ }^{14}$ found a dose-dependent, progressive increase in serum bilirubin in infants delivered by high-dose or prolonged oxytocin infusion techniques. Our results did not support this finding, nor did the serum bilirubin concentrations differ significantly between the high- and low-dose regimens of group $C(P>0.05)$. We cannot therefore agree with Ghosh and Hudson, ${ }^{15}$ who contended that a reduced oxytocin dosage would "virtually eliminate neonatal hyperbilirubinaemia of unknown origin." Calder et al ${ }^{16}$ suggested that interruption of pregnancy rather than the direct effect of oxytocin causes hyperbilirubinaemia. Induced labour may lack the normal hormonal surge of spontaneous labour ${ }^{1718}$ that may be responsible for fetal hepatic enzyme induction. Thus in induced labour there would be no enzyme induction. ${ }^{19}$

The direct association between oxytocin and a raised bilirubin concentration may be spurious. Indeed, Calder $e t a l^{16}$ found higher neonatal bilirubin concentrations after labour induced by either oxytocin or dinoprostone than in those of spontaneous onset. Our findings agree with those of Gould et $a^{10}$ but differ from those of Wong and Wood ${ }^{20}$ and Arthur et al, ${ }^{21}$ as we could find no significant difference between breast-fed and artificially fed babies. We also could not confirm that previous oral contraceptive use had any icterogenic effect on the newborn. ${ }^{22}$

We thank Drs J Mackie, C Mann, and M Miller, of the obstetric staff, and $W M$ McCrae, of the paediatric staff, and the sisters and nurses of the labour suite for their help.

\section{References}

${ }^{1}$ Bradford, W P, and Gordon, G, fournal of Obstetrics and Gynaecology of the British Commonwealth, 1975, 75, 698 .

2 Turnbull, A C, and Anderson, A B M, fournal of Obstetrics and Gynaecology of the British Commonwealth, 1968, 75, 24.

${ }^{3}$ Francis, J G, Turnbull, A C, and Thomas, F F, fournal of Obstetrics and Gynaecology of the British Commonwealth, 1970, 77, 594.

${ }^{4}$ Scott, J S, Proceedings of the Royal Society of Medicine, 1972, 63, 698.

5 Liston, W A, and Campbell, A I, British Medical fournal, 1974, 3, 606.

6 Ghosh, A, and Hudson, F P, Lancet, 1972, 2, 823.

' Davies, D P, et al, British Medical fournal, 1973, 3, 476.

${ }^{8}$ Roberts, G, and Weaver, A, Lancet, 1974, 1, 935.

${ }^{2}$ Davidson, D C, Ford, J A, and McIntosh, W, British Medical fournal, $1973,4,106$

10 Gould, S R, et al, British Medical fournal, 1974, 3, 228.

11 Thiery, M, et al, Lancet, 1975, 1, 161.

12 White, D, Haidar, G A, and Reinhold, J G, Clinical Chemistry, 1958, 4 211.

${ }^{13}$ Zueler, W W, and Brown, A K, American fournal of Diseases of Children, $1961,101,87$.

${ }^{14}$ Beazley, J M, and Alderman, B, British Fournal of Obstetrics and Gynaecology, 1975, 82, 265.

15 Ghosh, A, and Hudson, F P, British Medical fournal, 1973, 3, 636.

16 Calder, A A, et al, Lancet, 1974, 2, 1339.

17 Murphy, B E P, American fournal of Obstetrics and Gynecology, 1973, 115, 521.

18 Cawson, M J, et al, fournal of Obstetrics and Gynaecology of the British Commonwealth, 1974, 81, 737.

19 Sims, D G, and Heligan, G A, British fournal of Obstetrics and Gynaecology, 1975, 82, 863.

20 Wong, Y K, and Wood, B S B, British Medical fournal, 1971, 4, 403.

21 Arthur, L J H, Bevon, B R, and Holton, J B, Developmental Medicine and Child Neurology, 1966, 8, 279.

${ }^{22}$ McConnell, J B, Glasgow,'J F T, and McNair, R, British Medical Fournal, $1973,3,605$.

(Accepted 4 November 1976) 